Studies in African Linguistics

Volume 14, Number 2, August 1983

\title{
THE SYNCHRONIC BEHAVIOR OF BASIC COLOR TERMS IN TSWANA AND ITS DIACHRONIC IMPLICATIONS*
}

Ronald P. Schaefer

University of Benin

\begin{abstract}
The synchronic distributional pattern of potential basic color terms in one dialect of Tswana is examined in a wide range of construction types. From this pattern the non-basic status of the term lèphùtsí emerges, as well as a constraint requiring the exclusion of animals from the semantic extension of basic terms designating hue. Accepting lèphùtsí as non-basic, however, leaves a pattern of semantic reference violating a widely assumed universal constraint governing historical stages in the evolution of color names. To resolve this dilemma, a comparative analysis of color term reference in the Sotho languages is undertaken. Based on this analysis, the semantic reference for one basic color term in Tswana is hypothesized to have undergone a historical change, whereby the universal constraints on color naming give way to the constraint governing basic terms for hue.
\end{abstract}

\section{Introduction}

The semantic categorization of the color domain in Tswana, a Southeastern Bantu language, appears on initial examination to challenge a theory of the historical evolution of color naming which has received wide recognition (Berlin and Kay [1969], Kay [1975], and Kay and McDaniel [1978]). More precisely, a system of color names obtained over a period of months from a Tswana informant appears inconsistent with predictions from this theory. To

*The generous and patient assistance of Ms. Leloba Young, a native speaker of Tswana from Serowe, Botswana made this study possible. In addition, the advice and encouragement of Paul De Wolf of the Institut für Ethnologie und Afrika-Studien at Johannes Gutenberg Universität, Mainz, FRG, is gratefully acknowledged as are the comments on an earlier draft of this paper by Brian MacWhinney of the Department of Psychology, University of Denver. The preparation of this paper was supported in part by NIMH Grant \#MH14644-04 and a Graduate Exchange Scholarship between the University of Kansas and Johannes Gutenberg University. 
establish this point, the synchronic distributional behavior of potential basic color terms will be examined in a wide range of construction types. On the basis of this behavior, we will argue that the inconsistency is due to a conflict between language specific and language general constraints.

\section{Review of Basic Color Terms}

Over the past decade, the theoretical foundation for a series of interlocking studies in linguistics, anthropology, psychology, and neurophysiology has been Berlin and Kay [1969]. Their investigation, based on experimental evidence and dictionary analyses of 98 languages, argued that the categorization of color by natural language is far from arbitrary, contrary to Gleason [1955] and Ullman [1962]. In each language they examined, no more than eleven, and no fewer than two, basic color terms could be identified, with each term across languages referring to one of eleven focal areas in the color spectrum. Concurrent with these synchronic claims, they postulated a relatively fixed universal sequence of stages through which a system of basic color terms would historically evolve. This sequence, originally interpreted as the successive encoding of the eleven foci, is shown in Table 1 .

Table 1. Evolutionary sequence on color terms from Berlin and Kay [1969]

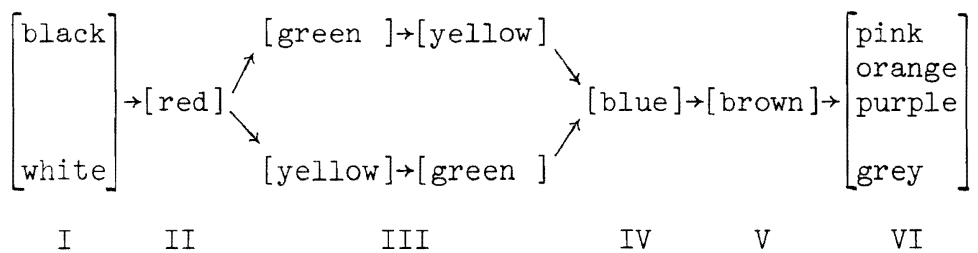

Subsequent research has altered the details of this sequence as well as sharpened our understanding of the nature and source of the categories underlying basic color terms. In the revised color term sequence, shown in Table 2, the stages are viewed as a progressive differentiation of the 
dimensions hue and brightness (Kay and McDaniels [1978]).1

Table 2. Revised evolutionary sequence of color terms from Kay [1975] and Berlin and Berlin [1975]

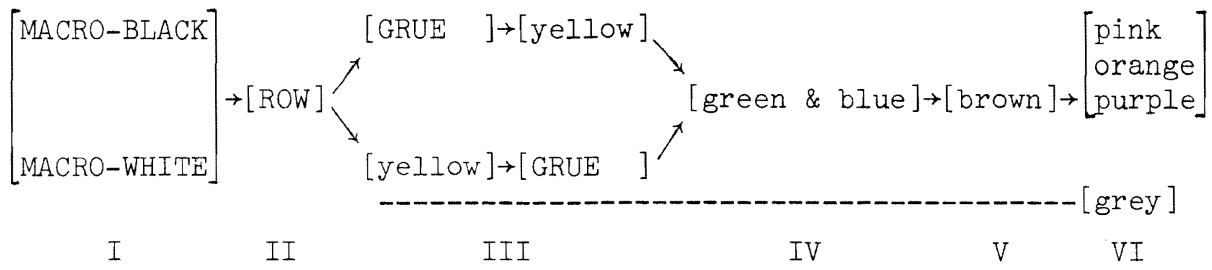

For example, the semantic categories in the first stage combine the brightness and hue dimensions such that foci identified by light/warm colors (MACRO-WHITE) and foci identified by dark/cool colors (MACRO-BLACK) are contrasted. In the second stage, the light/warm category is differentiated as a light (white) and a warm (red) category. Hue and brightness, along with saturation, also serve as the traditional dimensions for analyzing color categorization. Of these, the role of saturation, referring to chromatic purity, is little understood, and, even today, only the dimensions hue and brightness have been linked to specific neurophysiological components (Bornstein [1973a,b] and McDaniel [1974]).

The revision of the color naming sequence has been strengthened by studies of synchronic variation (Kay [1975] and Berlin and Berlin [1975]). Though all speakers of a language may not manifest a uniform stage in their color naming behavior, they do apparently manifest adjacent stages. The general finding is that development of new basic terms from non-basic terms, and distribution of basic and non-basic terms across dialects, conforms to the stages delineated in the revised Berlin and Kay sequence. Basic color term systems existing in different dialects of a language should thus mani-

The color foci for the categories identified with capital letters are: BLACK, GREEN, and BLUE for MACRO-BLACK; RED, YELLOW, and WHITE for MACRO-WHITE; RED and YELLOW for ROW; and GREEN and BLUE for GRUE. 
fest a single stage. For example, if a system representative of a dialect contains a basic term for BLUE and GREEN, it should also contain a basic term for YELLOW. Subsequent discussion herein will take up this prediction as it applies to the data from Tswana.

Based on recent studies, it is apparent that there may be psychophysiologically natural points in the color spectrum which ground the semantic categorization of color. Despite this grounding, the linguistic task of identifying basic color terms has proven problematic for a number of investigators, Wescott's [1970] analysis of Bini, a Kwa language of Africa, being a case in point. Wescott attempted to identify basic color terms by using the Berlin and Kay [1969] criteria, but they proved indeterminate in assigning Bini to one of the original diachronic stages. ${ }^{2}$

To strengthen the means for determining basic color terms, Westcott [1970] posited additional criteria. ${ }^{3}$ What is significant about these criteria is that they flesh out the general criterion of "similar distribution" advanced by Berlin and Kay [1969] and call attention to the value of extensive examination of color term distribution. Accordingly, the criteria of Berlin and Kay, combined with those from Wescott, were used to identify a set of potential basic color terms in the Tswana data under consideration.

Two dominant properties of the distributional behavior of these terms will receive attention. The first involves the single term lèphùtsí, which

2The criteria of Berlin and Kay [1969] specify that a basic color term should be the following: it should be monolexemic, its meaning should not be included in that of any other term, it should not be restricted to a narrow class of objects, it should be psychologically salient, it should have the same distribution as other basic terms, it should not name an object having that color, and it should not be a load word.

${ }^{3}$ The supplemental criteria proposed by Wescott [1970] include: polylexicity (the number of words for each color term), polytypy (the number of parts of speech represented by each color term), polymorphy (the number of allomorphs for each color term), onymicity (the extent a color term is used as the name of a person or place), and metaphoricity (the extent a color term is used in figurative expressions). 
deviates from the distributional pattern established by the other potential basic color terms. The second involves a pattern of complementary distribution within this set of terms.

\section{Basic Color Terms in Tswana}

3.1. Distribution of lèphutsí. In Berlin and Kay [1969] one of the principle criteria defining basic terms is their similar, if not identical, pattern of distribution. The behavior of the Tswana color term lèphùtsí does not meet this criterion. In an extremely wide range of construction types, the distributional behavior of lèphùtsí, meaning YELLOW, is irregular. An initial argument supporting this conclusion is the abstract noun construction. In order to refer to the abstract nature of a color, the Class 7 singular marker, bò- , is prefixed to the relevant color term root. As the construction types in Tables 3 and 4 reveal, this marker is not prefixed to lèphitsí.

Table 3. Class 7 singular constructions

$\begin{array}{ll}\text { 1. bò-ǹtšhó ké-mmálá ká-sètšwánà } \\ \text { black } & \text { be color in Tswana } \\ \text { 'black } & \text { is a color in Tswana' }\end{array}$

2. bò-šwéú ké-mmmálá kà-sètšwánà

'white is a color in Tswana'

3. bò-húbídú ké-mmálá ká-sètšwánà 'red is a color in Tswana'

4. bò-tàlá ké-mmálá ká-sètšwánà 'green is a color in Tswana'

5. lèphùtsí ké-mmálá ká-sètšwánà 'yellow is a color in Tswana'

6. bò-pùtšwà ké-mmálá ká-sètšwánà 'blue is a color in Tswana'

7. bò-sètıhá ké-mmálá ká-sètšwánà 'grey is a color in Tswana' 
Table 4. Class 7 singular constructions

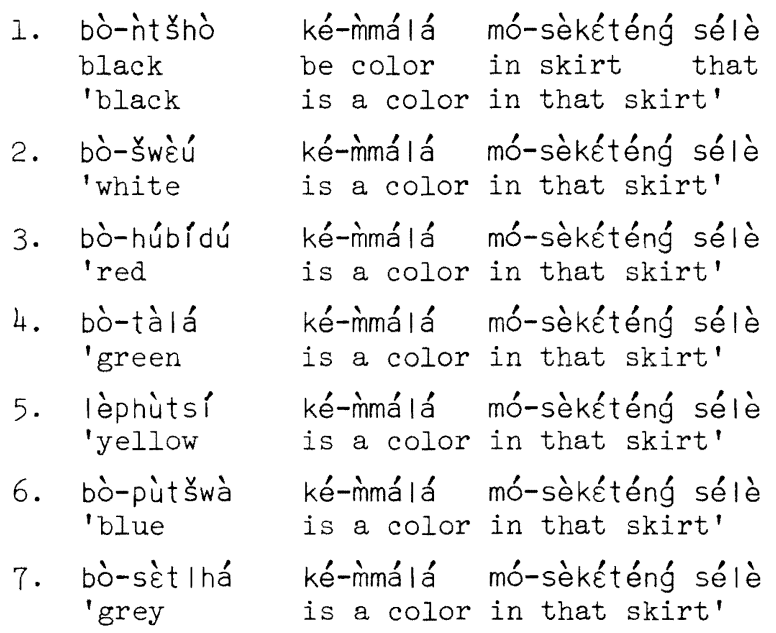

The irregularity of lèphitsí is demonstrated further by its dual meaning. According to Berlin and Kay's [1969] criteria, a basic color term should not name a color and an object possessing that same color, e.g. gold as the name of an object and a color in English. Consider then the behavior of color terms in Table 5, where a set of simile constructions employing each term is introduced. lèphùtsí occurs both as a term for color, YELLOW, and as a term for an object manifesting that color, a pumpkin. None of the other potential basic terms exhibits this behavior.

A third argument showing the irregular behavior of lèphùtsí is found in constructions where color terms are adjoined to the different class prefixes marking the descriptive copulative. Tables $6,7,8,9,10$, and 11 offer a representative sampling of descriptive copulative constructions. The irregular patterning in these constructions is evident: lèphùtsí does not adjoin with the first person singular marker kèmò- , the Class 1 singular marker mò- , the Class 1 plural marker bábá-, the Class 4 singular marker sésé-, and the class 5 plural marker dídí- . More specifically we notice that the second syllable of two syllable markers is deleted while single syllable markers are deleted altogether. 
Table 5. Simile constructions

$$
\begin{aligned}
& \text { 1. é-ǹtšhò } \\
& \text { it be black lááká bò-síxò } \\
& \text { 'it is black like the night } \\
& \text { 2. é-tšhwèu night' } \\
& \text { 'it is white láká lè-rù }
\end{aligned}
$$

Table 6. Descriptive copulative constructions with the

$$
\text { first person singular marker }
$$

1. kè-mò-ǹtšhò xò-xó-fétà

$$
\text { I be black you be surpassed }
$$

'I am blacker than you'

2. kè-mò-šwèú xò-xó-fétà

'I am whiter than you'

3. kè-mò-húbídú xò-xó-fétà

'I am redder than you'

4. kè-mò-tàlá xò-xó-fétà

'I am greener than you'

5. kè-lèphùtsí xò-xó-fétà

'I am yellower than you'

6. kè-mò-pùtšwà xò-xó-fétà

$$
\text { 'I am bluer than you' }
$$

7. kè-mò-sètIhá xò-xó-fétà

'I am greyer than you' 
Table 7. Descriptive copulative constructions with the Class 1 singular marker and present tense

1. mò-ngwè lé mó-ngwé ó-mó-ǹtšhò one and one be black 'everyone is black'

2. mò-ngwè lé mó-ngwé ó-mó-šwèú 'everyone is white'

3. mò-ngwè lé mó-ngwé ó-mó-húbídù 'everyone is red'

4. mò-ngwè lé mó-ngwé ó-mó-tàlá 'everyone is green'

5. mò-ngwè lé mó-ngwé ó-léphùtsí 'everyone is yellow'

6. mò-ngwè lé mó-ngwé ó-mó-pùtšwà 'everyone is blue'

7. mò-ngwè lé mó-ngwé ó-mó-sèt I há 'everyone is grey'

Table 8. Descriptive copulative constructions with the Class 1 singular marker and past tense

1. mò-ngwè lé mó-ngwé ó-nè á-lé mó-ǹt šhò one and one be past black 'everyone was black'

2. mò-ngwè lé mó-ngwé ó-nè á-lé mó-ร̌wèú 'everyone was white'

3. mò-ngwè lé mó-ngwé ó-nè á-lé mó-húbídù 'everyone was red'

4. mò-ngwè lé mó-ngwé ó-nè á-lé mó-tàlá 'everyone was green'

5. mò-ngwè lé mó-ngwé ó-nè á-lé léphùtsí 'everyone was yellow'

6. mò-ngwè lé mó-ngwé ó-nè á-lé mó-pùtšwà 'everyone was blue'

7. mò-ngwè lé mó-ngwé ó-nè á-lé mó-sèt l há 'everyone was grey' 
Table 9. Descriptive copulative constructions with the Class 1 plural marker

1. bó-tlhé bá-bá-ǹtšhò all of them be black

'all of them are black'

2. bó-tlhé bá-bá-šwèú

'all of them are white'

3. bó-tlhé bá-bá-húbídù

'all of them are red'

4. bó-tlhé bá-bá-tàlá

'all of them are green'

5. bó-tlhé bá-léphùtsí

'all of them are yellow'

6. bó-tIhé bá-bá-pùtšwà

'all of them are blue'

7. bó-tlhé bá-bá-sc̀t Ihá

'all of them are grey'

Table 10. Descriptive copulative constructions with the Class 4 singular marker

1. sélé sésé-ǹtšhò

that yonder be black

'that is black'

2. sélé sésé-ร̌wèú

'that is white'

3. sélé sésè-húbídù

'that is red'

4. sélé sésé-tàlá

'that is green'

5. sélé sé-léphùtsí

'that is yellow'

6. sélé sésé-pùtšwà

'that is blue'

7. sélé sésé-sètlhá

'that is grey' 


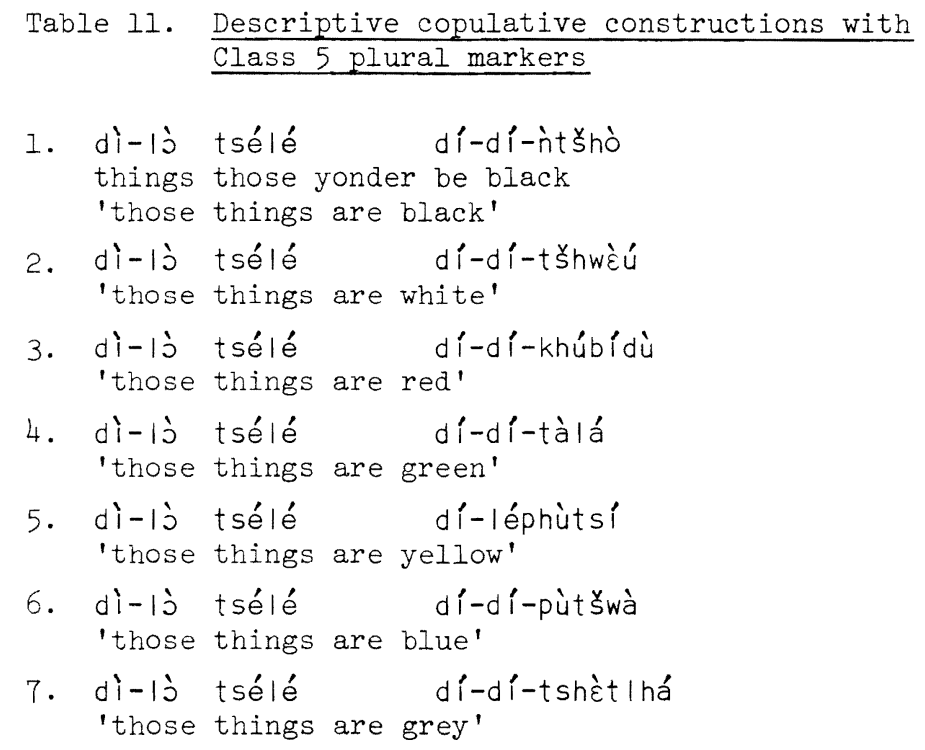

A more subtle argument substantiating the distributional irregularity of lèphùtsí is found in descriptive copulative as well as identificative copulative constructions. In both of these copulative construction types, the Class 5 singular prefix assumes the surface form én- with monosyllabic root forms and é- with multisyllabic roots. Irrespective of surface form, the Class 5 prefix, when adjoined to root initial segments with a low strength value, conditions the application of a phonological strengthening process. ${ }^{4}$ The weak initial segments of the color terms -šwéú ( $\left.\mathrm{s}>t s ̌ h\right)$, -húbídù $(h>k h)$, and -sèt $h a ́$ ( $s>t s h)$, in Tables 12 and 13, manifest strengthening when the Class 5 prefix is adjointed. 5 In contrast, the weak initial segment of lèphùtsí, /1/, does not manifest strengthening. If it did, the resulting form would be tèphùtsí. What might motivate this pattern of irregular behavior?

\footnotetext{
${ }^{4}$ See Cole [1955] and Schaefer [1980, 1982] for discussion of the strengthening process.

${ }^{5}$ At some earlier diachronic stage, BLACK was probably encoded by -šò , becoming - ̀̀tšhò under strengthening and reanalyzed as a single lexical unit.
} 
Table 12. Descriptive copulative constructions with the Class 5 singular marker

1. à-é-ǹtšhò

Q - it be black

'is it black?'

2. à-é-tšhwèú

'is it white?'

3. à-é-khúbídù

'is it red?'

4. à-é-tàlá

'is it green?'

5. à-é-léphùtsí

'is it yellow?'

6. à-é-pùtšwà

'is it blue?'

7. à-é-tshèt Ihá

'is it grey?'

Table 13. Identificative copulative constructions with the Class 5 singular marker

1. ké-é-ǹtšhò

it be one black

'it is a black one'

2. ké-é-ť̌hwèú

'it is a white one'

3. ké-é-khúbídù

'it is a red one'

4. ké-é-tàlá

'it is a green one'

5. ké-é-léphùtsì

'it is a yellow one'

6. ké-é-pùt šwà

'it is a blue one'

7. ké-é-tshèt Ihá

'it is a grey one' 
Partial motivation for the failure of lèphùtsí to manifest the strengthening process may be due to its morphological structure. In its non-color usage, the lexical unit lèphùtsí is composed of the class 3 singular prefix lè- adjoined to the root -phùtsí. Class 3 in Tswana is a miscellaneous class, consisting of names for parts of the body, some animals, plants and collective nouns. The class 3 singular prefix lè- thus has a morphological status equivalent to the various prefixes not manifested in the previous construction types. It is perhaps then the morphological heritage of lèphùtsí that accounts in part for its irregular behavior.

The composite morphological structure of lèphitsí, the color term, is revealed in some construction types. Intensifier constructions, requiring reduplication of a color term root, are presented in Tables 14 and 15 . These constructions indicate that only a portion of the lexical form meaning YELLOW,

-phitsí, is reduplicated. A similar partial segmentation under reduplication is not manifested by any of the remaining color terms. Based on these intensifier constructions, it would appear that the irregular distributional behavior of lèphitsí is a reflection of its morphological structure prior to becoming a term for color.

Distributional irregularity within the system of potential basic color terms is not entirely confined to lèphùtsí. The term for BLUE, -pùtšwà , exhibits a degree of irregular patterning, though it is not as consistent or widespread as the pattern we have already witnessed. In Tswana, a color term can be used in forming personal names by prefixing to it the Class 1 singular marker mò- . Using the resulting stem as a base, one can also express the location or place of this person's clan by prefixing to it the locative marker xá- . A list of constructions expressing personal names and the locations of individuals with these names is shown in Table 16 . As can be seen, the prefix mò- in the name and location constructions is deleted before lèphùtsí . Deletion, surprisingly, also occurs before -pùtšwà . One last argument supporting the irregular behavior of lèphùtsí, and to some extent of -pùtšwà, can be discerned in figurative expressions. Figurative expressions provided by my informant for each of the basic color 
terms are presented in Tables 17, 18, and 19.

Table 14. Descriptive copulative intensifier constructions with the Class 9 marker

1. xóxó-ǹtšhò-ǹtšhò

it be black black

'it is completely black'

2. xóxó-šพย̀ú-šพย̀ú

'it is completely white'

3. xóxó-húbî́dù-húbídù

'it is completely red'

4. xóxó-tàlá-tàlá

'it is completely green'

5. xó-léphùtsí-phùtsí

'it is completely yellow'

6. xóxó-pùtšwà-pùtšwà

'it is completely blue'

7. xóxó-sغ̀t Ihá-sغ̀t I há

'it is completely grey'

Table 15. Descriptive copulative intensifier constructions with the Class 5 marker

1. é-ńtsé ìtšhò-ǹtšhò

it become perfect black black

'it has become exceedingly black'

2. é-ńtsé tšhwèú-tร̌hwèú

'it has become exceedingly white'

3. é-ńtsé khúbídù-khúbídù

'it has become exceedingly red'

4. é-ńtsé tàlá-tàlá

'it has become exceedingly green'

5. é-ńtsé lèphùtsí-phùtsí

'it has become exceedingly yellow'

6. é-ńtsé pùtšwà-pùtšwà

'it has become exceedingly blue'

7. é-ńtsé tshèt Ihá-tshèt Ihá

'it has become exceedingly grey' 
Table 16. Name and location constructions with the Class 1 singular marker

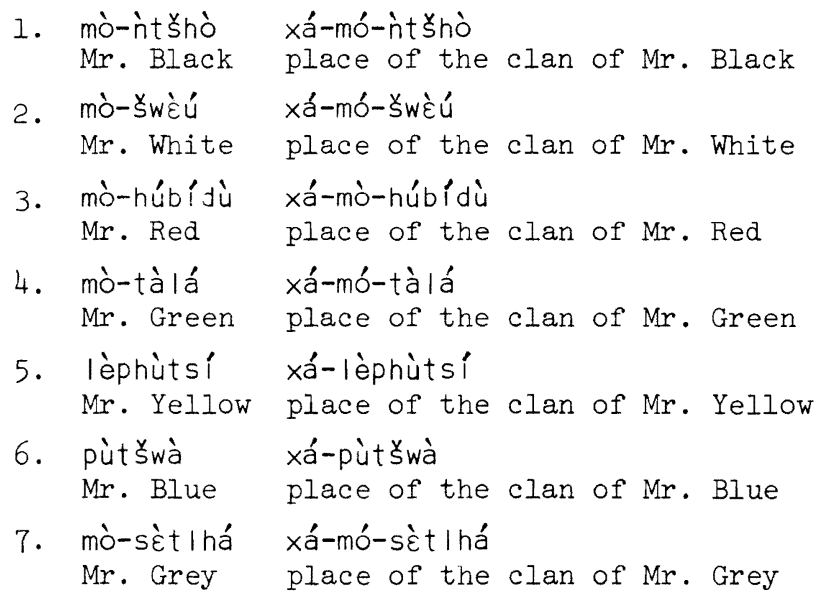

Table 17. Figurative expressions involving the Tswana color terms

1. xó-nè xó-lè lèfifl xó-ré tšhò

it be past dark it said black

'it was dark, it said black'

2. ó-nè á-i-tshásîtsé lè-tsòkú á-ré šwèú

he past he himself put on ochre he said white

'he had put on ochre, he said white'

3. ó-nè á-i-tshásîtsé lè-tsòkú á-ré húbè

'he had put on ochre, he said red'

4. nóxá é-nè é-rápálétsé mó-sè-tlhàrénǵ é-ré tálà snake be past it stretched out in a tree it said green

'a snake was stretched out in a tree, it said green'

5. - - -

6. mà-rù á-nè á-à-póxîlè lè-wápí lé-ńtsé lé-ré pùtšwà clouds past they dispersed the sky it past it say blue 'the clouds had dispersed, the sky was saying blue'

7. ó-nè á-i-têil wé ké-lè-fátshé á-ré sètlhá he past he himself beaten up by world he said grey 'he had been beaten up by the world, he said grey' 
Table 18. Figurative expressions involving the Tswana color terms

1. kè-mó-bò-ǹt šhòng̀

I inside blackness

'I am lost'

2. ké-mò-thò yóó-pèló tšhwèú

person who be hearted white

'he is a person who is white hearted'

3. kè-ḿ-mát là ká-mà-t Ihó á-mà-húbídù

I am look for with eye which be red

'I am looking for him with the red eye'

4. - -

5. - - -

6. --

7. ké-mò-thò yóó-pèlò tshèt Ihá

'he is a person who is grey hearted'

Table 19. Figurative expressions involving the Tswana color terms

1. á lè-káù lélé-t šhwànà

what youth who be black

'what a black youth'

2. á lè-káù lélé-šwánà

'what a white youth'

3. á mò-sé-tsànà yóó-mà-rámá ámà-húbítswànà what a girl who be cheek that be red

'what a girl who is red cheeked'

4. á mà-hùlò ámà-tálàná

what pasture which be green

'what a green pasture'

5. - - -

6. --

7. -- 
In the first type of figurative construction, lèphùtsi is the only color term for which an expression is lacking. In the second type, a figurative expression could not be formed with -tàlá, -pùtšwà , and lèphùtsí . In the final type of expression, -sèt lhá and lèphùtsí do not participate. According to Wescott's [1970] criteria, (see also Derrig [1978]) basicness in the color domain is indexed by occurrence in figurative expressions and by the range of this occurrence. That is, the longer a term has referred to color, the greater the likelihood that it will be used in figurative expressions. Since lèphùtsí does not enter into any figurative expressions, its status as a basic term is definitely suspect. To a lesser degree, -pùtšwà is also suspect. Its behavior pattern, however, may reflect the fact that, next to lèphùtsí, it is the most recent addition to the set of Tswana basic terms.

3.2. Complementary distribution of basic terms. A second pattern characterizing color terms within the basic set is one of complementary distribution. At the core of this pattern is a co-occurrence constraint which differentially affects potential basic color terms in Tswana. This pattern argues that at the semantic level two sub-classes of basic color terms are recognized in Tswana. One class is composed of terms designating color on the brightness dimension: -ǹtšhò , -šwèú, and -sètlhá . The other, in contrast, is composed of terms designating color on the hue dimension: -húbídù, -tàlá, -pùtšwà , and lèphùtsí .

As a background for viewing these two classes of basic terms, the following may be helpful. Tswana has a large number of terms which ascribe a color, a combination of colors, or a combination of color and other prominent marking, e.g. horns, to cattle and other animals. A representative sampling of these terms is listed in Table 20. As the glosses indicate, not every term can be ascribed to cattle, some can only be ascribed to sheep. More thorough discussion of these terms is precluded by limitations on the length of the present paper. It is the existence of these terms, however, to which we wish to call attention at this time. 
Table 20. A sample of terms which ascribe color to animals (male and female) in Tswana

1. bòbírwà bòbírwánà

2. bòdílúdì bòdílót sànà

3. bòfàtshwà bòfàtshwànà

4. bòfìfàdù bòfìfàt šwànà

5. bòfitšhwà bòfittšhwànà

6. bògwàrìpà bògwàrì pànà

7. bògwèbà bògwèbànà

8. bòhúnóù bòhúnwánà

9. bòkhùkhwà bòkhùkhwànà

10. bònà á bònáánà

11. bòngòlò bòngòl wànà

12. bòǹkgwè bògwànà

13. bònt I hwá bòt I hwànà

14. bòràmàgà bòràmàgànà

15. bòròkwà bòròkwànà

16. bòsàmpà bòsàmpánà

17. bòsumú bòsumúnyánà

18. bòt Ihàbà bòt I hàbánà

19. bòtùbà bòtùbànà

20. bòwèbù bòkwèbù 'black, only of sheep'

'black and white spotted, zebra'

'black and white in a large pattern'

'black'

'very dark brown, of cattle and horses'

'red and white, running into one another'

'red and white in small spots'

'red, bay colored, reddish brown'

'brown with yellow at extremities, or yellow with brown at extremities, of goats and dogs'

'red and white in a large pattern'

'black with white or yellow underparts, of goats and dogs'

'red, black with white along spine and underparts'

'dark brown, chocolate colored, of sheep'

'large spotted brown and white, maybe black'

'brown, dark red, yellowish red'

'white and red striped or streaked'

'red, black with white extending to face, and possible throat and belly'

'brown turning to yellow at extremities, or yellow turning to brown at extremities, cattle'

'coffee colored, fawn, yellow'

'grey roan, red roan'

Returning to the main issue, an initial argument substantiating a pattern of complementary distribution within the set of basic terms rests on the Class 7 prefix. As shown earlier, one refers to the abstract quality of a color, e.g., blackness, by prefixing the Class 7 singular prefix bòto a color term. To the resulting stem, the form -ànà can be suffixed. This marker, shown in Table 21 constructions, denotes either femaleness of 
the cattle species or diminutiveness (endearment), when adjoined to a potential color term. (Maleness and non-diminutiveness are unmarked.) Table 21. Construction involving the Class 7 and the

$\begin{array}{lll}\text { 1. bò-ǹtšhò } & \text { bò-šwànà } & \text { 'blackness' } \\ \text { 2. bò-šwću } & \text { bò-šwàánà } & \text { 'whiteness' } \\ \text { 3. bò-húbídù } & \text { bò-húbìtswánà } & \text { 'redness' } \\ \text { 4. bò-tàlá } & \text { bò-tàlánà } & \text { 'greenness' } \\ \text { 5. lèphùtsí } & & \text { 'yellowness' } \\ \text { 6. bò-pùtšwà bò-pùtšwànà } & \text { 'blueness' } \\ \text { 7. bò-sètlhá bò-sc̀tıhánà } & \text { 'greyness' }\end{array}$

Not all potential basic color terms can adjoin with the suffix -ànà to convey both of these meanings. Notice first that it does not adjoin with lèphùtsí to convey either the diminutive or female meaning. More significant is a constraint extending beyond lèphùtsí, namely that potential basic terms designating hue are never ascribed to female cattle. The color terms -húbídù, -tàlá, and -pùtšwà, when adjoined to the suffix -ànà, can only refer to diminutiveness (or endearment). The referential scope of the terms -ìtšhò, -šwéú, and -sغ̀t।há stands in contrast. The latter terms, all designating colors on the brightness dimension, can adjoin with -ànà and refer either to diminutiveness or femaleness. In other words, both meanings of the suffix -ànà can be conveyed with basic terms designating color on the brightness dimension. The unmarked forms in Table 21 (those in the left hand column) abide by the same constraint, i.e. terms designating hue (including lèphùtsí ) cannot be ascribed to male cattle, while terms designating brightness can.

A second argument substantiating complementary distribution within the set of basic terms is based on the root -phólòxólò. This root form, meaning ANIMAL, co-occurs with only a subset of the basic color terms, as shown in Tables 22 and 23. 
Table 22. Constructions involving the root form meaning ANIMAL
1. é-nè é-lé phólòxólò é-ǹtšhò
it be past animal black
'it was a black animal'

2. é-nè é-lé phólòxólò é-tšhwèú

'it was a white animal'

3. - - -

4. - -

5. - -

6. - - -

7. é-nè é-lé phólòxólò é-tshèt I há

'it was a grey animal'

Table 23. Constructions involving the root form meaning ANIMAL

1. fá-xòngwé dì-phólòxólò tsédí-ǹtšhò xà-dí-bónáxálè sometimes animals which be black not they seeable 'sometimes animals which are black are not seeable'

2. fá-xòngwé dì-phólòxólò tsédí-tšhwèu xà-dí-bónáxálè 'sometimes animals which are white are not seeable'

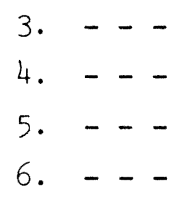

7. fá-xòngwé dì-phólòxólò tsédí-tshèt Ihá xà-dí-bónáxálè 'sometimes animals which are grey are not seeable'

Examination of these tables indicates that -phólòxólò only occurs with -ǹtšhò , -šwèú, and -š̀tlhá . The form meaning ANIMAL, therefore, does not co-occur with basic terms designating hue. We have thus bolstered our argument that there is a systematic constraint, specified by the domain ANIMAL, which governs the semantic extension of potential basic color terms. Although not obviously tied to the domain of cattle, a third argument supports the pattern of complementary distribution within the set of potential basic color terms. This argument pivots on the behavior of the 
derived verb suffix -hàlà ( fàlà in some dialects). As Cole [1955] states, -hàlà regularly is suffixed to roots denoting qualities, such as color terms, to express an inchoative meaning, i.e. the coming into existence of a state. The form -hàlà is also conjoined with the causative marker, giving the form -hàtsà, and suffixed to basic terms. The resulting form refers to causing a state to come into existence. It is the complementary distribution of basic color terms in expressions of inchoative and causative meaning to which we now turn.

Inchoative constructions involving potential basic color terms will be discussed first. In addition to -hàlà, the so-called deficient verb -ńná can also express the inchoative meaning. Tables 24 through 29 offer sample constructions expressing the inchoative meaning. As we can see in Table 24, the marker -ńná co-occurs with each potential basic term, irrespective of whether it designates color on the brightness or hue dimension. However, the marker -hàlà, in Table 25, does not behave in a similar fashion, co-occurring only with the brightness terms -ǹtšhò , -šwèú, and -š̀tlhá . The variety of constructions expressing an inchoative meaning in the tables above substantiate this pattern of complementary distribution, those with future and past tense in Tables 26 and 27, and those with perfective aspect in Tables 28 and 29. The distribution of the marker -hàlà is thus restricted compared to the marker -ńná, for it fails to co-occur with basic terms designating color on the hue dimension.

Causative constructions involving the potential basic color terms disclose an identical pattern of complementary distribution. Just as constructions with the marker -ńná express the inchoative meaning alongside those with -hàlà, so constructions with the marker -dìrà express a causative meaning alongside those with the marker -hàtsà, the causative form of -hàlà. And as -hàlà did not co-occur with color terms designating hue, -hàtsà does not co-occur with terms designating hue. Sample causative constructions are shown in Tables 31 through 33. 
Table 24. Inchoative constructions with the deficient verb -ńna
1. é-ńná ìt šhò
it becomes black
'it is becoming black'
2. é-ńná tšhwèú
'it is becoming white'
3. é-ńná khúbídù
'it is becoming red'
4. é-ńná tàlá
'it is becoming green'
5. é-ńná léphùtsí
'it is becoming yellow'
6. é-ńná pùtšwà
'it is becoming blue'
7. é-ńná tshèt I há
'it is becoming grey'

Table 25. Inchoative constructions with -hala and -ńa in

1. é-á-ǹtšhò-hàlà

it black become

'it is becoming black'

2. é-á-šwèù-hàlà

'it is becoming white'

3. é-ńná khúbídù

'it is becoming red'

4. é-ńná tàlá

'it is becoming green'

5. é-ńná léphùtsí

'it is becoming yellow'

6. é-ńná pùtšwà

'it is becoming blue'

7. é-á-sèt Ihà-hàlà

'it is becoming grey' 

Table 26. Inchoative constructions with -hàlà and -ńná in
1. é-tlá-à -ìtšhò -hàlà
it future black become
'it will become black'
2. é-tlá-à -šwèu -hàlà
3. é-tlá-à-ńná khúbídù
it future become red
'it will become red'
4. é-tlá-à-ńná tàlá
'it will become green'
5. é-tlá-à-ńná léphùtsí
'it will become yellow'
6. é-tlá-à-ńná pùtšwà
'it will become blue'
7. é-tlá-à-š̀t Ihà-hàlà
'it will become grey'

Table 27. Inchoative constructions with -hàà and -ńná in past tense
1. é-nè é-ńtšhó -hàlà
it past be black become
'it was becoming black'
2. é-nè é-šwéú -hàlà
'it was becoming white'
3. é-nè é-ǹná khúbídù
'it was becoming red'
4. é-nè é-ǹná tàlá
'it was becoming green'
5. é-nè é-ǹná léphùtsí
'it was becoming yellow'
6. é-nè é-ǹná pùtšwà
'it was becoming blue'
7. é-nè é-sét Ihá-hàlà
'it was becoming grey' 
Table 28. Inchoative constructions with -hà à and -ńná in perfective aspect

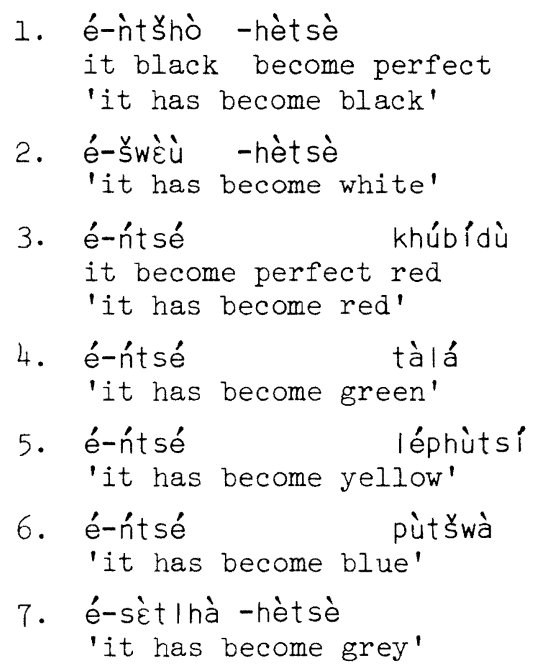

Table 29. Inchoative constructions with the deficient verb -ńná and perfective aspect
1. é-ńtsé $\quad$ ǹtšhò
'it has become black'
2. é-ńtsé
'it has become white'
3. é-ńtsé khúbídù
'it has become red'
4. é-ńtsé
tà lá
'it has become green'
5. é-ńtsé léphùtsí
'it has become yellow'
6. é-ńtsé
pùt šwà
'it has become blue'
7. é-ńtsé tshèt Ihá
'it has become grey'


Table 30. Causative constructions with -dìrà and -hàtsà

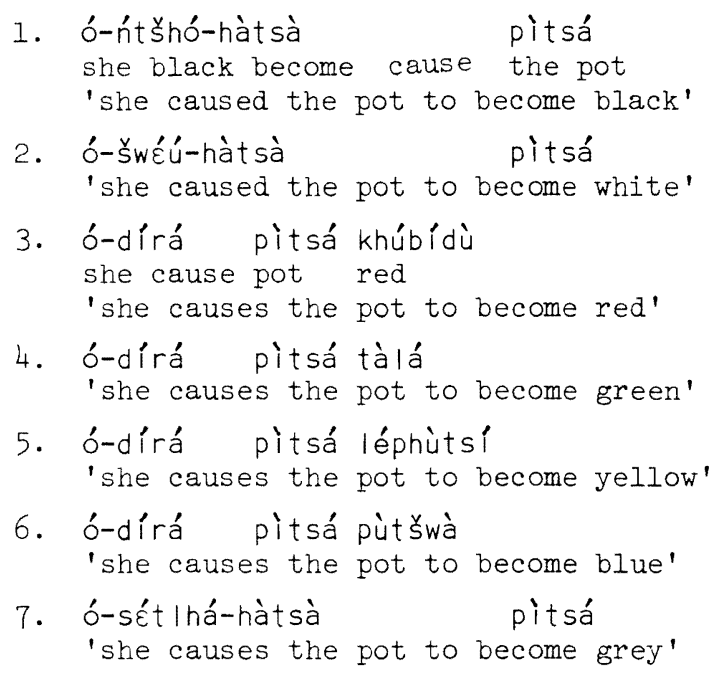

Table 31. Causative constructions with -dirà in perfective aspect
1. ó-dir-ílé pitsá ǹtšhò she make perfect pot black 'she made the pot black'
2. ó-dir-ílé pitsá tšhwèú
'she made the pot white'
3. ó-dir-ílé pitsá khúbídù
'she made the pot red'
4. ó-dir-ílé pitsá tàlá
'she made the pot green'
5. ó-dir-ílé pitsá léphùtsí
'she made the pot yellow'
6. ó-dir-ílé pitsá pùtšwà
'she made the pot blue'
7. ó-dir-ílé pitsá tshèt Ihá
'she made the pot grey'



Table 32. Causative constructions with -hàlà in perfective

1. ó-ǹtšhó-hádítsé pitsá she black become cause perfect iron pot

'she blackened the iron pot'

2. ó-šwèú-hádîtsé ìkxhó

'she whitened the clay pot'

3. - -

4. - -

5. - - -

6. --

7. ó-sèt Ihá-hádítsé lètsóxòlá xáxwé ká-mólòrà she grey become cause perfect hand her with ash 'she greyed her hand with ash'

Table 33. Causative constructions with -hàlà in perfective aspect

1. ó-è -ńtšhó -háditsè he it black become cause perfect

'he caused it to become black'

2. ó-è-šwźú-hádi t sè

'he caused it to become white'

3. - -

4. - -

5. - -

6. - - -

7. ó-è-sét I há-hádit sè

'he caused it to become grey'

The consistent and widespread pattern of complementary distribution just examined appears to reflect a semantic constraint operating within the set of color terms in Tswana. Underlying this constraint on basic terms is the recognition of two sub-classes, classes which appear semantically natural in that each is defined by one of the dimensions giving rise to the categorization of color, hue, and brightness. 
3.3. Consequences of the distribution pattern. The two patterns characterizing the distribution of potential basic color terms lead to the following consequences. Relative to the behavior of other terms, the irregular behavior of lèphitsí argues that it is not a basic color term. The fact that it is object-derived strengthens this argument. Next to lèphùtsí, the most recent addition to the set of basic color terms seems to be

-pùtšwà, whose distribution deviates in small measure from that of the other terms. The fact that the behavior of -pùtswà conforms to the overall pattern of the other terms establishes, nonetheless, that it is a basic term. Finally, since the terms -ǹtšhò, -šwéú, and -sغ̀t!há have the least restricted distribution, being ascribable to animals as well as objects, perhaps only these terms should be considered basic.

Careful examination shows all but one of these consequences to be theoretically problematic. Rejecting all but -ìtšhò, -šwèú, and

-š̀tlhá as basic terms seems inadequate given the general character and use of the entire set of potential terms. In some ways, rejecting all but these terms would be comparable to rejecting yellow, blue, and green as basic color terms in English because each does not combine with the morphological marker -en, i.e. *yellowen, *bluen, and *greenen. These Tswana terms do highlight a significant fact, namely a systematic point of contact and overlap between the set of basic color terms and the set of auxiliary color terms referring to animals. ${ }^{6}$

\footnotetext{
${ }^{6}$ The extent to which similar patterns of overlap exist in other dialects of Tswana and other languages in cattle herding economies would seem to deserve attention. An intriguing issue raised by the overlap of terms in the basic and auxiliary sets is why terms designating brightness, rather than hue, overlap. Further investigation might explicate the motivation for this particular type of overlap. The set of auxiliary color terms in Tswana raises another intriguing issue. Berlin and Kay [1969] correlate the general expansion of color term systems with a cultural variable, technological advance. The pattern of color term expansion they envisage, though, is one where a semantic category emerges from a set of object categories having no previous reference to color. The situation in Tswana stands in contrast. In Tswana, an elaborate system of categories designating both the hue and brightness of color in the animal domain is available at the semantic level. In some languages, therefore, a color category may not emerge as basic at the semantic level so much as
} 
To return to the set of consequences, rejecting lèphùtsí as a basic color term poses a serious theoretical issue. Rejecting lèphùtsí results in a diachronic stage not recognized by the revised, or the original, evolutionary sequence of color terms shown at the outset. There is no allowance for a stage where BLUE and GREEN are lexicalized but YELLOW is not. Of course, one could claim that the dialect under examination stands as an exception to the postulated universal diachronic sequence. This explanation seems too hasty at present though. As an alternative, one might claim that -pùtšwà, as well as lèphùtsí, is not a basic term. The dialect of Tswana examined herein would then be at Stage III in the revised evolutionary sequence. The regular distributional behavior of -pùtšwà argues against such a conclusion however. Still a third alternative rests with a comparative and historical analysis of Tswana color terms. Information gleaned from comparative and historical sources, indicating the semantic extension and semantic reference of forms cognate with the Tswana color terms, may provide a situation under which we can mollify the effect of rejecting lèphùtsí as a basic color term.

\section{Comparative Analysis of Color Terms}

The evidence available from historical sources on first glance seems to impede rather than facilitate understanding of color term development in Tswana. Especially affected are the terms -pùtšwà and -š̀tıhá. The Rev. T. Brown's Setswana-English:English-Setswana Dictionary, the only extant dictionary of Tswana, was published in 1925 in its revised form. In the main, the semantic record provided by Brown's dictionary agrees with the system of semantic reference outlined by the preceding examples, except for the semantic reference of -sìtlhá. Close inspection of the entries in this dictionary, moreover, indicates that the inclusion of animals or non-animals in the semantic extension of color term is not consistently noted.

transfer from a non-basic to the basic color domain. It is perhaps differences between the processes of emergence and transfer that will lead to a clearer understanding of the situation in Tswana. 
According to the color term data discussed thus far, the term -sغ̀t há refers to GREY and the term lèphìtsí refers to YELLOW. The Brown dictionary, in contrast, lists -sغ̀tlhá as referring to YELLOW. No examples illustrating this usage are provided. A second contrast involves the form -pùtšà , and its morphological variant -pùdùd, which are listed as referring to DARK GREY, BLUE and DARK BLUE, GREY, respectively. ${ }^{7}$ In the data examined thus far, -pùtšwà has referred only to BLUE. We will take up these problems of reference shortly.

Additional information bearing on the referential scope of the potential color terms is available in dictionaries of languages genetically related to Tswana, Northern Sotho and Southern Sotho. 8 Overall, the names these dictionaries provide for the primary colors conform with the pattern established by Brown and my informant, except for the naming of YELLOW, BLUE, and GREY. In the Southern Sotho-English Dictionary edited by Paroz [1961] and the Comparative Northern Sotho Dictionary:Northern Sotho-Afrikaans/English [1977], the term -tàlá refers to GREEN or BLUE, i.e. Berlin and Kay's GRUE. This fact distinguishes Northern and Southern Sotho from Tswana, for Brown's dictionary and my informant indicate that -tàlá refers only to GREEN. ${ }^{9}$ A difference in referential scope also characterizes the term -pùtšwà . Brown glosses it as BLUE or BLUE GREY, and my informant indicated that it referred to BLUE. In Northern and Southern Sotho, -pitšwà is glossed as GREY, referring to colored objects or animals. No mention is made of the BLUISH GREY found in the lexical entries in Brown.

${ }^{7}$ A process of haplology, combined with the palatalization process discussed in Cole [1955], d > ts, could specify the relatedness of the forms

-pùtšwà and -pùdùdù. The entries for these terms also suggest that they may not have been ascribed to cattle or animals. The entry for -pùdùi , at least in Brown [1924], makes no reference to cattle. Under -pùdùdù, the sample illustrations are non-animal: blue sky and blue clothes. A separate term, -kwèbú, is listed as referring to the BLUE of an ox.

${ }^{8}$ See Doke [1954] for discussion of the Sotho family of languages.

${ }^{9}$ See Squires [1942] for evidence that the term -tàlá may have referred to BLUE and GREEN in some northern Tswana dialects in more recent times. 
For present purposes, the most conspicuous similarity between the dictionary entries for Northern Sotho, Southern Sotho, and Tswana involves the form

-sèt Ihá. In both the Northern and Southern Sotho dictionaries a form -sèhlá, cognate with the Tswana form -sغ̀t Ihá, refers to YELLOW. Examples illustrating this color in the Southern Sotho dictionary include a chestnut horse and a pale, light-skinned man or animal. Presumably, -sc̀hlá was attributed to animals, whereas Brown's dictionary for Tswana fails to provide a similar level of detail for -š̀tlhá. Nonetheless, an intriguing hypothesis, derived from these examples, is that the historical antecedent of

-š̀hlá/-sètlhá referred to a faint YELLOW, a desaturated YELLOW, which allowed for the "light-skinned" and "pale man" examples. But before going further, let us attempt to clarify the discussion thus far by listing in Table 34 the color terms obtained from the various dictionaries and from my informant, along with the semantic reference of each term.

Table 34. Color terms obtained from various dictionaries of the Sotho languages and from my informant

\begin{tabular}{|c|c|c|c|c|}
\hline $\begin{array}{l}\text { Tswana } \\
\text { (Brown) }\end{array}$ & N. Sotho & S. Sotho & $\begin{array}{c}\text { Tswana } \\
\text { (Informant) }\end{array}$ & Referent \\
\hline 1. -ntšho & -tsho & $-t$ sho & -ntšho & BIAACK \\
\hline$-s ̌ w \varepsilon u$ & $-s ̌ w \varepsilon u$ & 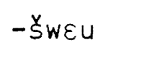 & $-s ̌ w \varepsilon u$ & WHITE \\
\hline -hubidu & -hubedu & -hubidu & -hubidu & RED \\
\hline 4. -tala & -tala & -tala & -tala & GREEN \\
\hline -set Iha & -schla & -schla & lephutsi & YELLOW \\
\hline $\begin{array}{l}\text { 6. -pucwa, } \\
\text {-pududu }\end{array}$ & -tala & -tala & -put šwa & BLUE \\
\hline 7. -pududu & -put šwa & $\begin{array}{l}\text {-putšwa, } \\
\text {-pududu }\end{array}$ & -set Iha & GREY \\
\hline
\end{tabular}

A further check on the referential scope of color terms in the Sotho languages is available in Louw [1957]. Louw compared the color terms ascribed to cattle in the three Sotho languages. Based on his analysis of one speaker from each language, -pùtšwà/-pùdùdù and -sغ̀t/há/-sc̀hlá refer to DARK GREY 
and YELLOW, respectively. The Tswana terms -sèt।há and -pùtšwà most likely were then ascribable to cattle at one point in their history.

The semantic information derived from these sources has clear implications for inferring the development of the referential scope of color terms in the Tswana dialect under consideration. In each of the non-Tswana dictionaries consulted, the term for YELLOW was cognate with the Tswana form -š̀tlhá . The saturation level of this YELLOW color, judging by the Southern Sotho record, appeared to be low, encompassing YELLOW, as well as a light colored, pale YELLOW. When my informant was confronted with the information that

-sìt Ihá referred to YELLOW, she indicated that perhaps the GREY color of a lion (a pale hue) was the intended meaning.

It seems reasonable to conclude from these different sources that at some earlier date, -sètlhá referred to a range of color encompassing desaturated YELLOW and LIGHT GREY. Such a conclusion seems in harmony with Christman's [1971] assertion that as hue becomes desaturated, it is perceived in terms of the brightness dimension, e.g. GREY.

A comparable conclusion seems warranted for -pùtšwà . The dictionaries assign to -pùtšwà, the meaning BLUE and DARK GREY in Tswana and GREY in Northern and Southern Sotho. For some earlier diachronic stage, it seems reasonable to postulate that the historical antecedent of -pùtšwà referred to a range of color which encompassed desaturated BLUE and DARK GREY.

Assuming the correctness of these postulates regarding the referential scope of -pùtšwà and -sètlhá, it appears that both referred at some earlier diachronic stage to a highly desaturated range on the hue dimension which naturally intermixed with the brightness dimension. Is there evidence from outside linguistics proper which could further substantiate these postulates? Seemingly supportive evidence is available in Bornstein [1973a,b].

\section{Additional Support for Comparative Analysis}

Bornstein [1973a,b] has offered a theoretical explanation for cultural differences in optical illusion susceptibility and color naming that is at base psychophysiological. Previous explanations of behavior in these two 
domains have assumed that across populations physiological structures involved in perceptual processing are identical. Bornstein, in contrast, calls attention to potential physiological differences in the pigmentation density of the ocular structures which process incoming perceptual information. In particular he points out a correlation between patterns of increased yellow pigmentation and reduced susceptibility to optical illusions. 10 For instance, populations in Africa, which exhibit high retinal pigmentation, have shown less susceptibility to the Muller-Lyer optical illusion than populations in Europe, which exhibit less retinal pigmentation [Berry 1971]. In the domain of color naming, the pigmentation of the ocular structure evinces a comparable effect.

Bornstein [1973a,b] examined primary color terms in over 145 different languages for what he termed "semantic confusions." A semantic confusion occurred when a single color term referred to more than one of the primary colors, i.e. BLACK, WHITE, RED, GREEN, YELLOW, and BLUE. His major finding was the high frequency with which BLUE was lexicalized with BLACK, GREEN, or both of these colors. A correlated set of confusions, though less pervasive, involved WHITE and YELLOW (GREY unfortunately is not considered a primary color).

To explain this "BLUE" confusion pattern, Bornstein [1973a,b] pointed out the phenomenal similarity between the color naming practices defining the pattern of BLUE confusion across languages and the color naming practices of individuals with weak blue-yellow vision. These individuals are characterized by a highly dense yellow pigmentation of the ocular structures. Probing further, Bornstein located the pattern of BLUE confusion primarily in areas of relatively intense sunlight populated by dark skinned peoples. In this highly sunlit environment, the adaptive function of increased pigment density is to absorb potentially harmful short wavelength radiation. More important, the

${ }^{10}$ See Segall [1979] and Jahoda [1971, 1975] for some counter-arguments to the Bornstein hypothesis. It is important to note that these arguments are not conclusive and frequently involve a within culture experimental design, such as comparing white and black skinned individuals living in a highly technological society. 
effect on color perception is to attenuate incoming visual stimulation of BLUE light and, so it appears, YELLOW light as well.

The referential scope of color terms among a population characterized by high pigment density, such as Tswana speakers, might then be expected to manifest a phenomenal similarity with the referential scope of color terms among a population characterized by weak blue-yellow vision. A quotation from Pickford [1951:103], where extensive investigation of color vision is reported, revealing a close affinity between the naming practices of blue-yellow weak individuals and Tswana speakers should not be surprising:

\footnotetext{
"With the yellow-blue blind and even the yellow-blue weak either or both blue and yellow are diminished in saturation compared with the normal. Dark grey tends to invade blue and light grey and white tends to invade yellow."
}

The phenomenal similarity between the color naming condition outlined by Pickford and the postulated scope of reference of the terms -pùtšwà (DARK GREY and BLUE) and sèt Ihá (LIGHT GREY and YELLOW) cannot be easily dismissed. The referential scope postulated for these terms may thus rest on a natural psychophysiological property of the visual system of Tswana speakers.

\section{Resolution of -š̀t Ihá Issue}

A major issue still remains. That is, was -sغ̀tlhá , or its historical antecedent, a member of the set of basic terms or the set of auxiliary terms, whose extension is confined to animals, when it did refer to YELLOW. If

-š̀t Ihá was a basic term referring only to YELLOW, why does it now, as a basic term, refer to GREY? On the other hand, if -sغ̀t।há, on becoming a basic term did not refer to YELLOW, but instead to GREY, then the revised evolutionary sequence of basic color terms is not satisfied (Kay [1975], Kay and McDaniel [1978]).

In order to choose between these alternatives, it seems advantageous to employ the construct "overburdening" discussed by Kristol [1980]. Two crucial aspects of semantic overburdening are pertinent to our discussion. First, the referential scope of a color term is subject to language general and language 
specific constraints. And second, the natural consequence of violating such a constraint is a reduction in referential scope.

Recall now from the data examined at the outset, the constraint governing the inclusion of animals and cattle in the semantic extension of some basic color terms. Specifically, terms designating a color on the hue dimension could not be ascribed to animals. Let us add to this the comparative data obtained from the Sotho languages, from which we postulated the semantic character of -sغ̀tlhá at some earlier diachronic stage. We found, to repeat, that -sغ̀t lhá referred to both the hue and brightness dimensions and included animals within its extension during that stage. This semantic condition, however, violates the constraint noted above, i.e. basic color terms designating hue in Tswana are not ascribable to animals. In other words, the semantic condition of -sètıhá is overburdened. To amend this condition, the referential scope of -sغ̀thá could be restricted to YELLOW and its extension could exclude animals, or its referential scope could be restricted to GREY and its extension allowed to include animals. Of these two semantic changes, the latter seems the path of least effort and the one which maintains the greater portion of -š̀tlhá's former semantic integrity, i.e. requiring only a change in referential scope rather than a change in reference and extension. This change would necessitate, however, the introduction of a new term for YELLOW, such as lèphìtsí, and set the stage for what appeared an exception to the postulated universal sequence of color term development.

7. Summary

To review, the distributional behavior of potential basic color terms in one dialect of Tswana was examined in a wide range of construction types. This behavior led to the rejection of one of the color terms, lèphùtsí, as a basic term and to the recognition of a language specific constraint requiring the exclusion of animals from the extension of basic terms designating hue.

Rejecting lèphùtsí proved problematic, since the remaining terms were inconsistent with universal constraints on the historical stages basic color 
terms should instantiate. After a comparison of color term semantics in the Sotho languages, a historical state of reference and extension for the Tswana term -sètlhá was postulated. Assuming the existence of this earlier semantic state made the resulting color terms consistent with universal constraints, although -sètlhá's meaning then violated the Tswana specific constraint governing the extension of hue terms. Apparently as a result of violating this language specific constraint, a change in the semantic character of -sèt lhá was necessitated, leading to a narrowing of its referential scope and the introduction of a new color term, lèphitsí.

\section{REFERENCES}

Anonymous, n.d. Comprehensive Northern Sotho Dictionary: Northern Sotho, Afrikaans/English. Johannesburg: J. L. Van Shaik LTD.

Berlin, B. and E. A. Berlin. 1975. "Aguarana color categories." American Anthropologist 2:61-87.

Berlin, B. and P. Kay. 1969. Basic Color Terms. Berkeley: University of California Press.

Berry, J. W. 1971. "Muller-Lyer susceptibility: culture, ecology or race?" International Journal of Psychology 6:193-197.

Bornstein, M. H. 1973a. "Color vision and color naming: a psychophysiological hypothesis of cultural differences." Psychological Bulletin $80: 257-285$.

Bornstein, M. H. 1973b. "The psychophysiological component of cultural differences in color naming and illusion susceptibility." Behavior Science Notes 8:41-101.

Brown, Rev. J. T. 1925. Setswana-English:English-Setswana Dictionary, third edition. Johannesburg: Pula Press.

Christman, R. J. 1971. Sensory Experience. Toronto: Intext Educational Publishers.

Cole, D. T. 1955. An Introduction to Tswana Grammar. Capetown: Longman. 
Derrig, S. 1978. "Metaphor in the color lexicon." In D. Farkas, W. M. Jacobsen and K. W. Todrys (eds.), Papers from the Parasession on the Lexicon, pp. 85-96. Chicago: Chicago Linguistic Society.

Doke, C. M. 1954. The Southern Bantu Languages. London: Oxford University Press.

Jahoda, G. 1971. "Retinal pigmentation, illusion susceptibility and space perception." International Journal of Psychology 6:199-208.

Jahoda, G. 1975. "Retinal pigmentation and space perception: a failure to replicate." Journal of Social Psychology 97:133-134.

Kay, P. 1975. "Synchronic variability and diachronic change in basic color terms." Language and Society 4:257-270.

Kay, P. and C. McDaniels. 1978. "The linguistic significance of the meanings of basic color terms." Language 54:610-646.

Kristol, E. 1980. "Color systems in southern Italy." Language 56:132-145.

Louw, J. A. 1957. "The nomenclature of cattle in the southeastern Bantu languages." Pretoria: Communications of the University of South Africa C,2.

McDaniel, C. K. 1974. "Basic color terms: Their neurophysiological bases." Paper presented at the American Anthropological Association, Mexico City.

Paroz, R. A. 1961. Southern-Sotho English Dictionary. Morija: Morija Printing Works.

Pickford, R. W. 1951. Individual Differences in Color Vision. London: Routledge and Kegan Paul.

Schaefer, R. P. 1980. "On the motivation and structure of a strengthening process in Tswana." In P. Hamel and R. Schaefer (eds.), Kansas Working Papers in Linguistics 5.2. Lawrence: University of Kansas.

Schaefer, R. P. 1982. "A strength hierarchy for a morphophonemic process in Tswana." Studies in African Linguistics 13:147-176.

Segall, M. H. 1979. Cross-Cultural Psychology: Human Behavior in Global Perspective. Monterey, CA: Brooks/Cole.

Squires, B. T. 1942. "Colour vision and colour discrimination amongst the Bechuana." Transactions of the Royal Society of South Africa 29:29-34. 
Ullman, S. 1962. Semantics. Oxford: Blackwell.

Wescott, R. W. 1970. "Bini color terms." Anthropological Linguistics 12: 349-360.

Witkowski, S. R. and C. H. Brown. 1977. "An explanation of color nomenclature universals." American Antrhopologist 79:50-57. 